\title{
FACTS, THREATS AND REDS: COMMON LAW CONSTITUTIONALISM AND THE RULE OF LAW
}

\author{
JOHN R MORSS*
}

In a concurring judgment in Thomas v Mowbray, a High Court of Australia case turning on the Constitutional validity of terrorism-related control orders, Callinan J offers a re-evaluation of the Court's earlier decision in the Australian Communist Party case to curtail executive power. According to Callinan J, factual matters knowable (but not known) at the time of the earlier decision might have given rise to a different outcome. In a dissenting judgment by Kirby $J$ in the same case the Court's reasoning in the Australian Communist Party case is robustly defended. These contested issues connect with the theoretical dispute between 'common law constitutionalism' and 'constitutional positivism' analysed by Dyzenhaus in the context of states of emergency where the limits of executive action and the role of supporting facts become particularly salient. They press the question of the status of the rule of law in the international as well as in the municipal sphere.

\section{INTRODUCTION}

Long after the waning of its political influence (although such an epitaph can only be tentative), the Australian Communist Party continues to exert an important influence on the jurisprudence of the Commonwealth. Thus the terrorism-related interim control order case of Thomas $v$ Mowbray ${ }^{1}$ includes a significant re-evaluation, on the part of Callinan J, of the High Court of

\footnotetext{
* Associate Head, Law School, Deakin University. Thanks to Oscar Roos for introducing me to Thomas' case, and to Rachel Carter for research assistance.

${ }^{1}$ Thomas v Mowbray (2007) 233 CLR 307.
} 
Australia's earlier decision in the Australian Communist Party case. ${ }^{2}$ Callinan J's proposition in Thomas is that factual matters of geopolitics not apparent at the time of the Communist Party case may, if known, have given rise to a different outcome, that is to say to an outcome endorsing the position of the executive of the day in its prohibition of communist activities. The specific point made by Callinan $\mathrm{J}$ is that the scale of the Soviet military and political threat towards, inter alia, Australia in the early years of the Cold War might have sufficed to influence the Court's deliberations over the constitutional legitimacy of the executive's attempted prohibition of the Party and its persecution of those identified as communists. In a dissenting judgment by Kirby J, on the other hand, the wisdom of the Court's reasoning in the Communist Party case - rejecting the arguments of the executive - is robustly defended. ${ }^{3}$

\section{A Dyzenhaus and Common Law Constitutionalism}

The decision in the Communist Party case is also defended in the academic writings of David Dyzenhaus as a shining example of 'common law constitutionalism'. ${ }^{4}$ It has been argued by Dyzenhaus that the bench of a Constitutional court such as the High Court of Australia is faced in its deliberations with a stark if frequently unacknowledged choice. Either it can treat the Federal (or correspondingly supreme) Constitution in an instrumental and a pragmatic manner as a document that 'merely' sets out a template for the separation of powers; or it can treat it as a document that manifests a set of higher values relating to the rule of law, of which the separation of powers is but a facet or an index, such that the Constitution instantiates a 'common law constitution'. ${ }^{5}$ Common law constitutionalism is therefore an orientation to constitutional aspects of the legal system which treats those aspects as embodying the values underpinning the common law. According to this viewpoint, it is a mistake to treat the separation of powers as significant or

\footnotetext{
${ }^{2}$ Australian Communist Party $v$ The Commonwealth (1951) 83 CLR 1. In the light of the central issues of Thomas v Mowbray, Callinan J's discussion of the Australian Communist Party case clearly has the status of obiter dicta.

${ }^{3}$ Thomas v Mowbray (2007) 233 CLR 307, 484 (Callinan J); 442 (Kirby J). Also see Oscar Roos, 'Alarmed, But Not Alert in the "War on Terror"? The High Court, Thomas v Mowbray and the Defence Power' (2008) 15 James Cook University Law Review 169, 200.

${ }^{4}$ David Dyzenhaus, The Constitution of Law: Legality in a Time of Emergency (2006) 73.

${ }^{5}$ Ibid 99. Common law constitutionalism is sometimes referred to by Dyzenhaus as the 'aspirational conception'. For a contrasting perspective see Jeffrey Goldsworthy, The Sovereignty of Parliament: History and Philosophy (1999). There is of course more (or sometimes less) to any Constitution than a provision for the separation of powers; however the separation of powers is an appropriate, as well as an iconic, focus for these issues.
} 
effective in itself. Rather, the separation of powers only 'works' to the extent that deeper values are being called upon and indeed implemented.

While the distinction may not always be patent either in the decision of the court or in the conscious awareness of the judges, it is undoubtedly a theoretically significant one. It connotes a choice to be made by the judiciary between posited law on the one hand, and a larger value system on the other, as providing the touchstone for judicial decision-making. Dyzenhaus urges that judges should make the latter choice (that is to say, in favour of common law constitutionalism). He refers to the former choice, unsurprisingly, as favouring a positivistic attitude, namely 'constitutional positivism'. ${ }^{6}$ According to Dyzenhaus, the common law constitution is

an evolving or living constitution ... [T]he judicial understanding of its content has been irrevocably changed by the international human rights regimes and other constitutional experiments of the last fifty or so years. ${ }^{7}$

\section{B Other Versions of Common Law Constitutionalism}

Common law constitutionalism has been said to characterise the recent decision of the House of Lords in Jackson v Attorney General, a case arising from UK legislation prohibiting fox-hunting, which raised constitutional questions relating to the status of the House of Lords. ${ }^{8}$ Writing about that case, Mullen observes, for example, that '[i]n recent years, the theory which has become known as "common law constitutionalism” has gained ground both among academic writers and the judges'.

In the context of a related debate - the debate over the desirability of entrenching constitutional provisions - the position of Waluchow has also been described, by Mildenberger, as representing 'common law constitutionalism'. ${ }^{10}$ The entrenching of particular constitutional provisions means that future generations of legislators have an extraordinarily high threshold to surmount if they wish to change such provisions. Waluchow's

\footnotetext{
${ }^{6}$ Ibid (Dyzenhaus) 16.

7 Ibid 190.

8 Jackson v Her Majesty's Attorney General [2005] UKHL 56; also see Jeremy Waldron, 'Are Constitutional Norms Legal Norms?' (2006) 75 Fordham Law Review 1697, 1702.

9 Tom Mullen, 'Reflections on Jackson v Attorney General: Questioning sovereignty' (2007)

27 Legal Studies 1, 13.

10 Joshua Mildenberger, 'Waldron, Waluchow and the Merits of Constitutionalism' (2009) 29 Oxford Journal of Legal Studies 71.
} 
position is supportive of such entrenching in principle, since it may be thought of as the manifestation of deep and long-standing moral commitments of a community. ${ }^{11}$ According to Waluchow, the constitution is a 'living tree' which 'grows and adapts to contemporary circumstances, trends and beliefs'. ${ }^{12}$

Waluchow's version of common law constitutionalism, which would thus seem highly compatible with Dyzenhaus', is contrasted by Mildenberger with the 'democratic majoritarianism' of Jeremy Waldron, for whom the entrenching of constitutional provisions represents 'the dead hand of the past' and is profoundly undemocratic. The position of Waluchow is not entirely identical with that of Dyzenhaus, and the position of Waldron is perhaps not adequately summed up as 'constitutional positivism,' but the basic contrast holds and the contrastive terms are useful ones. Common law constitutionalism and its 'fellow-travellers', represent the claim that a judicial appeal to larger values will sometimes be needed, if only 'when push comes to shove' and in particular in the situation of emergency as discussed in Thomas $v$ Mowbray. Constitutional provisions will never be enough in themselves, argue Dyzenhaus and Waluchow, to protect basic freedoms.

\section{Constitutional Positivism}

In contrast, constitutional positivism denies the claims made on behalf of common law constitutionalism, treating it indeed as a dangerous form of 'backsliding' from democratic governance. This position, if not the positivist label, is endorsed by Lynch and Reilly who, in discussing the counterterrorism legislation under consideration in Thomas $v$ Mowbray, observe that there is no need for recourse to the rule of law 'as a fount of common law constitutionalism'.

Instead, the separation of powers doctrine provides a clear framework through which that broader assumption [of the rule of law] may be brought to bear upon this particular legislative initiative. ${ }^{13}$

\footnotetext{
${ }^{11}$ WJ Waluchow, A Common Law Theory of Judicial Review: The Living Tree (2007) 203; WJ Waluchow, 'Legality, Morality, and the Guiding Function of Law' in Matthew H Kramer, Claire Grant, Ben Colburn and Antony Hatzistavrou (eds), The Legacy of H.L.A. Hart: Legal, Political and Moral Philosophy (2008) 85, 95.

${ }^{12}$ Waluchow, A Common Law Theory of Judicial Review, above n 11, 55 (footnote omitted).

${ }^{13}$ Andrew Lynch and Alexander Reilly 'The Constitutional Validity of Terrorism Orders of Control and Preventative Detention’ (2007) 10 Flinders Journal of Law Reform 105, 129.
} 
Thus constitutional positivists and their fellow travellers assert that proper procedure is adequate, at least in principle. For example, they assert that the separation of powers is adequate to serve its intended democratic functions of setting limits on executive power, and that majoritarian processes in parliament are adequate to express the will of the people, without recourse to entrenched decisions of previous generations.

\section{National Emergencies and Executive Autonomy}

The distinction between constitutional positivism and common law constitutionalism is of course a variant of the hundreds of years' war in legal philosophy between natural law and legal positivism. ${ }^{14}$ In times of tranquillity the distinction may be somewhat academic and may not matter a great deal. But in times of emergency, when the executive branch is tempted or pressurised into overlooking constraints on its power, ${ }^{15}$ the distinction may be crucial - as indeed Dyzenhaus has stressed. Thus, as Dyzenhaus points out, these theoretical questions are central to the debate over the proper limits of executive action in the context of national emergencies.

These questions have arisen in many places and over many centuries, not least in the place and time in which common law and presumably a 'common law constitution' emerged: early modern England. The England of the Tudors, and the England-plus-Scotland of the Stuarts and their successor regimes, provide numerous examples of the effective, if scarcely democratic, management of state emergency. ${ }^{16}$ The point of course is that while the questions have arisen,

\footnotetext{
${ }^{14}$ John R Morss, 'Part of the Problem or Part of the Solution? Legal Positivism and Legal Education' (2008) 18 Legal Education Review 55; John R Morss, 'Pride’s Purge: A Puritanical Response to Dr Allan's “A Modest Proposal”' (2005) 30 Australian Journal of Legal Philosophy 82.

${ }^{15}$ Greg Carne, 'Hasten Slowly: Urgency, Discretion and Review - A Counter-Terrorism Legislative Agenda and Legacy' (2008) 13 Deakin Law Review 49; Julie Cassidy, 'Hollow Avowals of Human Rights Protection - Time for an Australian Federal Bill of Rights? (2008) 13 Deakin Law Review 131; Conor Gearty, 'The Superpatriotic Fervour of the Moment' (2008) 28 Oxford Journal of Legal Studies 183-200; Scott Guy and Barbara Hocking, 'Why Military Matters: Re Colonel Aird; Ex Parte Alpert and the 'Service Connection' Test versus the 'Service Status' Test: Competing Approaches to the Triggering of the Defence Power' (2008) 13 Deakin Law Review 177.

${ }^{16}$ Eg Star Chamber, discussed by Geoffrey Robertson, 'Fair Trials for Terrorists?' in Richard Ashby Wilson (ed) Human Rights and the War on Terror (2005) 169, 171. Also see Eric Heinze, 'Power Politics and the Rule of Law: Shakespeare's First Historical Tetralogy and Law's “Foundations”' (2009) 29 Oxford Journal of Legal Studies 139; and, on Hale, see Gerald Postema, 'Conformity, Custom, and Congruence: Rethinking the Efficacy of Law' in Matthew H Kramer, Claire Grant, Ben Colburn and Antony Hatzistavrou (eds), The Legacy of H.L.A. Hart: Legal, Political and Moral Philosophy (2008) 45, 46.
} 
debate has been suppressed in these circumstances: debate might be said to be the first victim of a state of emergency, just as logic is 'the first casualty of war'. ${ }^{17}$

The need for debate, and the political suppression of that debate, arise irrespective of whether the emergencies occur as a response to international political movements or to international terrorism, or indeed to events defined as internal. The distinction between internal and international threats is itself of limited value: Geoffrey Robertson, for example, nicely refers to 'terrorism, or treason as it was called then' in reference to $17^{\text {th }}$ century England. ${ }^{18}$ In this connection it might also be recalled that when 'Lord Haw-Haw' (William Joyce), Irish-American radio propagandist for the Nazi regime during World War II, went to the gallows in post-war London, it was for treason. ${ }^{19}$

\section{The Australian Communist party CASe RECONSTRUCTED}

In connection with the analysis of the role of the judiciary in limiting executive power, Dyzenhaus has argued that the decision of the High Court of Australia in the Australian Communist Party case represented a triumph for common law constitutionalism, a view that would seem to be shared in effect by at least one recent member of that Court, namely Michael Kirby.

In the Australian Communist Party case the High Court considered the constitutional legality of a proscription of the Australian Communist Party by the Menzies administration in 1950. Notably, the proposed legislation went beyond the abolition of the Party itself and of affiliated organisations to the imposition of significant limitations in respect of public service employment for any person 'declared' by the executive to be a communist. ${ }^{20}$

Indeed it was as a result of the Commonwealth executive overreaching itself, in thus encroaching on the judicial function, that 'the Communist Party Dissolution Act foundered'. ${ }^{21}$ The usual role of legislation would be to define

\footnotetext{
${ }^{17}$ Robertson, above n 16, 169.

${ }^{18}$ Ibid 171.

${ }^{19}$ Joyce v Director of Public Prosecutions [1946] AC 347.

${ }^{20}$ George Winterton, 'The Communist Party Case' in HP Lee and George Winterton (eds), Australian Constitutional Landmarks (2003) 108, 117.

${ }^{21}$ Ibid 127.
} 
prohibited acts or omissions - in this case subversive mischiefs to be factually linked to named individuals only by means of the independent judicial process with its procedural safeguards. Instead, the Act declared in its preamble the factual connection between the subversive acts and what were in effect named individuals (viz persons identified as communists). The constitutionally guaranteed separation of powers had been compromised.

Significantly, comparable legislation (that is, legislation to regulate voluntary associations) enacted by any of the Australian States, rather than by the Commonwealth, might not have been unconstitutional. Australia's federal Constitution limits, and to some extent defines, the extent to which powers of the States are referred to the Commonwealth as such. Thus it was 'the institution of federalism that incidentally provided the civil rights protection for which [the Communist Party case] has become celebrated. ${ }^{22}$

\section{A The Fear of Communism}

Governmental prohibitions of, or constraints upon, the functioning of communist organisations are premised on the characterisation of communism as an international conspiracy. ${ }^{23}$ Witch-hunt parables for inquisitions into communist infiltration (as generally understood to be exemplified by Miller's play The Crucible) are a reminder of the medieval and early modern sense of Satanic influence as a kind of international conspiracy. This discourse remained significant in the context of state fears of international religious conspiracies, for example by militant Catholics in a Protestant England, ${ }^{24}$ pursuing what Geoffrey Robertson has called 'Jesuit religious terrorism'. ${ }^{25}$ In the twentieth century, state fears (in the West) of international communist conspiracies, and their mirror-image in the communist East, represent at least to some extent the descendant of those earlier manifestations of the siege mentality in the executive. In a more intense and brutal form, so do the regimes of state repression that characterised Argentina and neighbouring

\footnotetext{
${ }^{22}$ Dan Meagher, 'Back to the Future: The War on Terror and its Impact on Civil Liberties' (2004) 15 Public Law Review 177, 178.

${ }^{23}$ Also see Martin Krygier, 'The Quality of Civility: Post-anti-communist Thoughts on Civil Society and the Rule of Law' in András Sajó (ed), Out of and Into Authoritarian Law (2002) 221.

${ }^{24}$ Nicholl refers to the dependence of the government under Elizabeth I on a 'maverick army of intelligencers and projectors' in the context not only of a genuine need for information by the executive but also 'political expediency, ... courtly in-fighting, [and] police-state repression': Charles Nicholl, The Reckoning: The Murder of Christopher Marlowe (1992) 265.

${ }^{25}$ Robertson, above n 16, 170.
} 
states in the 1970 s. $^{26}$ In the present millennium cognate state fears are centred on international terrorist conspiracies.

\section{B The Communist Party Case, Constitutional Positivism and Dyzenhausian Hermeneutics}

As noted above, the outcome in the Communist Party case has been attributed to the High Court majority giving due weight to the federal provisions in Australia's Constitution, an approach apparently more in keeping with 'constitutional positivism' than with an attachment to common law values as such as guiding the evaluation of statute. Dyzenhaus recognises the plausibility of this 'constitutional positivist' reading ${ }^{27}$ but discerns the need for a deeper layer of interpretive methodology. According to Dyzenhaus, the High Court's detailed attention to the constitutional text reflects a state of 'dissonance' on the part of the (majority) bench, in relation to the alternative explanatory frameworks that he has described (common law and positivist). Dyzenhaus goes so far as to suggest an attitude of avoidance on the part of the bench, that is, say a refusal to confront what he calls 'the only solid answer to the question of the legal limits on the power of both Parliament and the executive'. ${ }^{28}$ This answer is, for Dyzenhaus, 'that the source of these limits is to be found in the common law, which supports both a constitutional doctrine of judicial independence and a sense of the fundamental values which that independence is supposed to serve'. ${ }^{29}$ More generally, for Dyzenhaus, 'a division of powers constitution offers an opportunity to judges minded to adopt an aspirational conception to hide that conception behind constitutional text'. However, he continues, 'it would be better for them to articulate their common law constitutionalism fully'.30

Dyzenhaus' hermeneutic account of the Communist Party case might be thought to be over-influenced by his theoretical position. The 'constitutional positivist' interpretation that he admits is the more plausible on its face needs to be corrected, he asserts, by hermeneutic analysis concerning psychological processes such as 'dissonance' and 'avoidance'. The issues Dyzenhaus has raised concerning the rationale for limits on the executive are more important

\footnotetext{
${ }^{26}$ Fernando Tesón, 'Liberal Security' in Richard Ashby Wilson (ed) Human Rights and the War on Terror (2005) 57, 58; Tesón continues: '[d]emocratic societies can be besieged as much by fundamental Islamic terrorists as by ... the Mafia or drug lords': at 59 (emphasis added).

${ }^{27}$ Dyzenhaus, above $n$ 4, 76.

${ }^{28}$ Ibid 86.

${ }^{29}$ Ibid.

${ }^{30}$ Ibid 72.
} 
than the matter of how convincing his academic account of one case may be said to be. In any event it is important to take account of the (albeit obiter) reconsiderations of the Communist Party case recently presented in the High Court itself in the case of Thomas $v$ Mowbray.

\section{Thomas v Mowbray: The High Court Revisits the Communist Party Case}

The litigation in Thomas $v$ Mowbray arose from the enactment of Division 104 of the Criminal Code (Cth), itself a governmental response to the 'War on Terror' environment after 9/11. Division 104 provides for control orders to be made against individuals associated with terrorist organisations, and an interim control order had been made by a Federal Magistrate against the plaintiff Thomas, imposing a curfew and reporting obligations on him and significantly restricting his activities. In concurring with the view that Division 104 is constitutionally valid, Callinan J drew extensive comparisons (and some important contrasts) with the enactment in question in the Communist Party case. This occasioned on the part of Callinan J a remarkable re-evaluation of the High Court's reasoning in that earlier case. Meanwhile, in a dissenting judgment, Kirby $\mathrm{J}$ strenuously defended the probity and wisdom of the Communist Party outcome. ${ }^{31}$

For Callinan J, the Commonwealth had in the earlier dispute unwisely sought to rely on the mere recital of facts in the preamble to the Communist Party Dissolution Act in order to sustain the invocation of the defence power in the Constitution. ${ }^{32}$ In other words the necessary 'constitutional facts' were not properly established. In the view of Callinan J, with the information available after the end of the Cold War the extent of the threat posed to Australia by international communism, especially as controlled from Moscow in those Cold War years, was factually established. The threat was in fact adequate to support the Commonwealth government's proposed legislation. That is to say, in Callinan J's view the invocation of the defence power was justified by the geopolitical situation in 1950 .

Callinan J's discussion of the Communist Party decision thus indicates that notorious factual information such as geopolitical facts should in principle be available to the High Court bench in its deliberations. This is not to say that

\footnotetext{
${ }^{31}$ In a previous dissent, Kirby J had argued that the Communist Party case shows the invalidity of any enactment or executive act that depends on 'the conclusive assertion or opinion of the Parliament (eg expressed in recitals to an Act) ... It remains for the judiciary in each contested case to interpret the applicable law': Al-Kateb v Goodwin (2004) 219 CLR 562, 618.

${ }^{32}$ Thomas v Mowbray (2007) 233 CLR 307, 486 (Callinan J).
} 
the outcome of the Communist Party case is being questioned by Callinan $\mathrm{J}$ there were serious flaws in the legislation at issue which justified the outcome. Nevertheless, 'subsequent events which might tend to falsify some of the factual assumptions upon which parts of the reasoning were based, should [not] be ignored'. Thus 'it is revelatory history itself, which gives rise to questions about aspects of the case'. ${ }^{33}$

The argument by Callinan $\mathrm{J}$ might be thought of as an application or a development of the appeal to political reality that had apparently been endorsed in 1999 in Sue v Hill. ${ }^{34}$ Here, the High Court had held that in the years since Federation, the UK had become a 'foreign power' in relation to section 44(i) of the Constitution such that dual British citizenship would disqualify an Australian citizen from election to the House of Representatives or to the Senate. Michael McHugh, a member of the High Court bench in Sue $v$ Hill, has referred to this decision favourably as an example of 'modern political perceptions [being] given precedence over the literal meaning of the terms of the Constitution'.

Whatever linkages are discerned between the disqualification (section 44(i)) issue in Sue v Hill and the retrospective Cold War issue raised by Callinan J in Thomas $v$ Mowbray, it may be argued that in both cases the competence of the High Court in relation to the prerogative of the executive is at stake. If only under traditional English common law, if not the common law understood as still obtaining alongside the Constitution of Australia, the identification of enemy states would seem a matter for the executive - ('The Prince', so to speak). Furthermore, one might have thought that the term 'foreign power' might also be a matter for executive discretion rather than judicial notice. This argument is rejected by the majority in Sue v Hill, for whom the decision with which the Court was faced was not about qualitative aspects of the relationship between states - proper matters for executive discretion - but merely (objectively, as it were) about 'questions of international and domestic sovereignty. ${ }^{36}$ In dissent, Callinan J points out in Sue v Hill, however, that

\footnotetext{
${ }^{33}$ Thomas v Mowbray (2007) 233 CLR 307, 503 (Callinan J).

${ }^{34}$ Sue v Hill (1999) 199 CLR 462.

${ }^{35}$ Michael McHugh, 'The Constitutional Jurisprudence of the High Court: 1989-2004' (2008) 30 Sydney Law Review 5, 25.

${ }^{36}$ Sue v Hill (1999) 199 CLR 462, 487 (Gleeson CJ, Gummow and Hayne JJ). At this point in the judgment footnote [50] points to theoretical questions on international law raised by HLA Hart's Chapter X in The Concept of Law (1961); on which also see Jeremy Waldron, 'Hart and the Principles of Legality' in Matthew H Kramer, Claire Grant, Ben Colburn and Antony Hatzistavrou (eds), The Legacy of H.L.A. Hart: Legal, Political and Moral Philosophy (2008) 67, 83; John R Morss, 'Sources of Doubt, Sources of Duty: HLA Hart on International Law' (2005) 10 Deakin Law Review 41.
} 
'foreign power' tends in various items of Australian legislation to connote an enemy, broadly speaking.

\section{The Separation of Powers and Five Types of Legal Fact}

The demarcation point between the powers of the executive and of the judiciary might not bear too much weight perhaps in the Sue v Hill situation. Electoral disqualification is not usually thought of as a matter of national security. However the assessment of military and political threat as in the case of the former USSR in the early 1950s would assuredly have been claimed by the executive as its own to make, if only with a view to precedent should it have neglected to do so. The important point here is that any proposal by the judiciary to widen the scope of judicial notice for the reception of factual information inevitably raises concerns, perhaps including concerns about laws of evidence and the role of expert witnesses. Where the facts at issue are geopolitical facts pertinent to national security, the concerns would include worries about the separation of powers.

In the context of Thomas $v$ Mowbray, Heydon $\mathrm{J}$ (also concurring) distinguishes five categories of 'facts which may have to be established in litigation'. ${ }^{37}$ Strictly speaking, rules of evidence apply only to the first category of facts (ordinary questions of fact as disputed by parties to private litigation). ${ }^{38}$ For the other categories broader criteria for judicial reception are appropriate. Thus, for 'facts going to the constitutional validity of statutes' ('constitutional facts'), the Court may take account of its members' broader knowledge of its society. ${ }^{39}$ Significantly, constitutional facts are often controversial and for that reason unavailable under conventional judicial notice. ${ }^{40}$ Heydon J's view of the acceptability of constitutional facts is in that respect somewhat broader, if anything, than that of Callinan J. The same judicial latitude, it is said by Heydon J, applies to facts in the fifth category to facts that go to 'the content and development of the common law'. ${ }^{41}$ Heydon J expresses a serious caveat concerning constitutional facts: '[i]f judicial power to find constitutional facts were wholly untrammelled, there would be risks of great abuse. ${ }^{42}$ It may well be that corresponding caution is

\footnotetext{
${ }^{37}$ Thomas v Mowbray (2007) 233 CLR 307, 512 (Heydon J).

${ }^{38}$ See John R Morss, 'Can Custom Be Incorporated in Law? On the Place of the Empirical in the Identification of Norms’ (2008) 53 American Journal of Jurisprudence 85, 91.

${ }^{39}$ Thomas v Mowbray (2007) 233 CLR 307, 519 (Heydon J).

${ }^{40}$ Ibid 517.

41 Ibid 512.

${ }^{42}$ Ibid 522.
} 
appropriate in regard to facts of the fifth category, although this would be to extrapolate Heydon J's point.

Some articulation of the fifth category of facts, in which judicial fact-finding contributes to the content and development of the common law, may be achieved by considering the way in which the common law constitution itself is said to evolve. As noted above, that constitution is, for Dyzenhaus, 'an evolving or living constitution'. Similarly, for Waluchow, the constitution 'grows and adapts to contemporary circumstances, trends and beliefs'. Such extra-judicial sources of influence on the common law are thus, in effect, granted the status of facts. For example, admitting aspects of international law, especially customary international law, into municipal common law, irrespective of statutory implementation, ${ }^{43}$ would seem to involve an appeal to facts rather than to judicial authority. This issue is explored further in Section IV below. It is somewhat ironic that common law constitutionalism, with its concern for values, comes to rely on the identification of some of those values as facts for legal consumption.

\section{The Common law, the Rule of LaW, and the SEPARATION OF POWERS}

\section{A Perceived Limitations of Constitutional Positivism}

According to Dyzenhaus, the turn to constitutional positivism 'with its insistence on the rigid separation of powers' is 'depressing' and 'a retreat'. ${ }^{44}$ Constitutional positivism for Dyzenhaus connotes a 'dualism' of, on the one hand, statute law and, on the other, the principles of the rule of law as manifested in the common law. ${ }^{45}$ Constitutional positivism therefore has an impoverished view of the rule of law. In contrast, according to Dyzenhaus, common law constitutionalism properly represents and articulates the rule of law. To express the Dyzenhausian dichotomy a different way, the choice is between 'thick' and 'thin' versions of the rule of law, where the latter (corresponding to constitutional positivism) is 'merely' procedural ${ }^{46}$ and the former (corresponding to common law constitutionalism) is enhanced or completed by recourse to a value system. That is to say that an adequate

\footnotetext{
${ }^{43}$ See Morss, 'Can Custom Be Incorporated in Law?', above n 38, 93.

${ }^{44}$ Dyzenhaus, above $\mathrm{n} 4$.

${ }^{45}$ Ibid 191.

${ }^{46}$ Ibid 199; on procedural justice, see John R Morss, 'Crime Stories: Posnerian Pragmatism, Rawlsian Pure Procedural Justice, and the Fictional Problem’ (2004) 9(2) Deakin Law Review 643.
} 
understanding of the concept of the rule of law requires, according to Dyzenhaus, reference to implicit value systems and to interpretive traditions that by definition transcend national legal systems and their positive enactments. ${ }^{47}$ Dyzenhaus' approach is holistic.

Constitutional positivism is said to be dualistic in three respects: 1 ) in the sense noted above; 2 ) in relation to its attitude to international law; and 3) in its approach to the law of emergency circumstances. ${ }^{48}$ As to the third of these, constitutional positivism is said to make the mistake of drawing a distinction between the prerogative state that responds to an emergency, and the 'rule-oflaw state' which operates between emergencies. ${ }^{49}$ Thus one of the ways in which, according to Dyzenhaus, constitutional positivism devalues or impoverishes the rule of law is in treating it as adequate for times of stability but inadequate for times of severe threat to the state.

Consistent with his general position, Dyzenhaus argues that the limitations of constitutional positivism arise from its narrow focus and its unwillingness to read beyond the text. For Dyzenhaus (as for Michael Kirby) constitutional positivism is an impoverished approach. In relation to judicial decisions on the limits of executive power, constitutional positivism is exemplified by the reliance by the judiciary on the separation of powers. Simply put, Dyzenhaus strongly asserts that the separation of powers, as provided in a constitutional document such as that of the Commonwealth of Australia or the USA, is insufficient by itself to protect the citizenry from the excesses of government. Instead, according to Dyzenhaus, such desirable protection calls for a cooperative and proactive endeavour on the part of the judiciary, the executive and the legislature, working towards shared goals: the rule of law as a troika, so to speak. ${ }^{50}$

\section{B The Separation of Powers}

Callinan J's 'Cold Warrior' outburst in Thomas $v$ Mowbray, if it may be thus described without disrespect, presents a challenge to our understanding of the separation of powers within the Australian Constitution. And the separation of powers is of immense significance in relation to the issuing of control orders and suchlike encumbrances on personal liberty, as directly examined in Thomas.

\footnotetext{
${ }^{47}$ Randy Peerenboom, 'The Future of Rule of Law: Challenges and Prospects for the Field' (2009) 1 Hague Journal on The Rule of Law 5.

${ }^{48}$ Dyzenhaus, above n 4, 191.

${ }^{49}$ Ibid.

${ }^{50}$ Ibid 147.
} 
That understanding is itself uncertain. The role of the executive branch, and the proper limits of its power within the federal polity, have resisted authoritative definition for some while. Winterton has commented on the relative neglect by commentators and indeed by the High Court itself of an examination of the executive power of the Commonwealth, observing that throughout the common law world at least, 'executive power has always been something of a mystery, frequently being defined merely as the "residue" of governmental powers after legislative and judicial powers are excluded'. ${ }^{51}$

The separation of powers as provided in the Constitution of Australia is understood by the High Court not merely on the basis of the textual provisions of the Constitution in itself, but also on the basis of its earlier deliberations on that document, that is to say on a common law tradition of some kind. The form taken by common law in the context of Australia's Constitution is substantially distinct from its form in its foreign origins. As Pamela Tate has observed:

Invoking the language and logic of the common law may distract from an appreciation of the historical force of the Constitution as the instrument that established the Australian federal system; an instrument dividing legislative, executive and judicial authority between the Commonwealth and the States and creating the federal judiciary as the final arbiter. ${ }^{52}$

In the same vein, Tate warns against an 'illusion of continuity' in the Constitutional role of common law. One must, according to Tate, be cautious about treating 'implied constitutional guarantees drawn from the [English] common law as comprising the "fundamental principles" upon which the Constitution is constructed'. ${ }^{53}$ Tate's observation brings the discussion back to the question of the role of common law constitutionalism as advocated by Dyzenhaus - not that Dyzenhaus can be accused of parochial attachment to the common law of England in particular, however. As explored further below, Dyzenhaus' argument is, in a sense, an international one. Brief consideration of these international dimensions helps to clarify the distinction

\footnotetext{
${ }^{51}$ George Winterton, 'The Relationship between Commonwealth Legislative and Executive Power’ (2004) 25 Adelaide Law Review 21, 21 (footnote omitted). Goldsworthy has commented that 'the provisions in Chapter II of the Constitution, dealing with the structure and powers of the executive government, are so terse and elliptical as to be positively misleading': Jeffrey Goldsworthy, ‘Australia: Devotion to Legalism' in Jeffrey Goldsworthy (ed), Interpreting Constitutions: A Comparative Study (2006) 106, 108.

${ }^{52}$ Pamela Tate, 'Some Observations on the Common Law and the Constitution' (2008) 30 Sydney Law Review 121, 123.

${ }^{53}$ Ibid.
} 
between constitutional positivism and the common law constitutionalism advocated by Dyzenhaus.

\section{THE INTERNATIONAL RULE OF LAW AND 'CONSTITUTIONALISATION' AT THE INTERNATIONAL LEVEL}

It is important to observe that Dyzenhaus' analysis represents not only a contribution to the public law of municipalities such as Australia, Canada or the USA, but also a contribution to debates in international law. For example, Dyzenhaus argues that constitutional positivism goes along with dualism at the international level, ${ }^{54}$ that is to say with the view that international agreements are external agreements entered into by the executive and not part of municipal law until and unless expressly so enacted. For Dyzenhaus, it is both more accurate and more desirable to treat international law and common law as two sides of the same coin. This is a version of the 'monist' approach to the status of international law vis-à-vis municipal law. For Dyzenhaus the law relating to human liberty and human rights is a seamless whole, along the lines advocated by Lauterpacht. ${ }^{55}$

Another debate in international law with which Dyzenhaus' work connects closely is the debate over the 'international rule of law'. Explorations of 'the rule of law' as an international phenomenon are thus of relevance. ${ }^{56}$ In a general sense, any notion of the rule of law must treat municipal legal systems in the plural, that is to say must posit an effect or status of law that applies conceptually to more than one jurisdiction. ${ }^{57}$ The concept of the rule of law is, so to speak, supranational or 'anational', an abstracted or general claim. While hardly trivial, this point is somewhat limited in itself. What is more challenging is the exploration of the rule of law as it applies to international

\footnotetext{
${ }^{54}$ Dyzenhaus, above n 4, 191.

55 Ibid 193; the monist approach is exemplified by the contemporary attitude of common law jurisdictions toward the direct incorporation of customary international law: see Morss, 'Can Custom Be Incorporated in Law?’, above n 38, 93.

56 Jeremy Waldron, 'The Rule of International Law' (2006) 30 Harvard Journal of Law and Public Policy 15, 25.

${ }^{57}$ Brian Tamanaha, On The Rule of Law: History, Politics, Theory (2004) 127; Brian

Tamanaha, Law as a Means to an End: Threat to the Rule of Law (2006).
} 
agreements, expectations and regulations, and to obligations on collectives ${ }^{58}$ or individuals deriving from international agreements.

In this context Waldron makes an important point concerning the difference between the scope of the rule of law in the case of individual natural persons and in the case of governments. With respect to individual citizens, the rule of law might be said to coexist with unregulated spheres of conduct - setting limits on and enabling various forms of conduct but not defining individuals' conduct in toto. This would be an orthodox liberal analysis. In contrast, Waldron argues, government action is entirely defined by adherence to rule of law; there are no legitimate residual 'pockets of unregulated discretion' or 'loopholes'. ${ }^{59}$ Government is fully constituted by law. And what obtains for municipal governments also obtains for the network of relationships between such governments (or other significant international entities) that is called international law. For international law is not a set of relationships among special kinds of otherwise anarchic individual. ${ }^{60}$ If it were, some "pockets of unregulated discretion’ might be legitimate - sovereign states would rightly treat international law as a regrettable but happily limited constraint on their freedom as individual actors. Instead, the sovereignty of a state is 'determined by the rules of the international order'. ${ }^{61}$ Rule of law in its international sense is constitutive of the legitimacy of the sovereign state.

Waldron's sense of the rule of law as comprehensively determinative of governmental and international action leaves no space for individualistic discretion on the part of the executive. Nor would it seem to leave space for the appeal to values that, according to Dyzenhaus, is needed to complete and to legitimise the rule of law. Indeed such appeals to values might be seen as exemplars of the proscribed discretion. Waldron's analysis - which, despite its theoretical theme, maintains a focus on the necessary constraint of executive powers - is extremely rich but it is at the same time 'thin'. That is to say it is procedure-based rather than content-based ('thick'); closer to constitutional positivism than to common law constitutionalism. Waldron's argument noted above therefore becomes a key contribution to the development of constitutional positivism.

In the municipal context, Waldron counters constitutional entrenchment, for example the entrenchment of bills of rights, with an argument from

\footnotetext{
${ }^{58}$ John R Morss, 'The Legal Relations of Collectives: Belated Insights from Hohfeld' (2009)

22(2) Leiden Journal of International Law 289.

${ }^{59}$ Waldron, above n 56, 19.

${ }^{60}$ Ibid 21, 25.

${ }^{61}$ Ibid 21.
} 
majoritarian democracy. The voice of the living should it is said be allowed to overrule the voice of the dead. This argument is of much less, if any, persuasiveness in the international sphere given that democracy at the international level remains elusive. ${ }^{62}$ Also, in the USA context in which Waldron is currently writing, some special factors apply to the evaluation of facts. ${ }^{63}$ Even so, Waldron's remarks would seem to contribute to an emerging international constitutional positivism, ${ }^{64}$ offering an alternative vision to the Dyzenhausian common law orientation.

At the same time Waldron's argument posits a constitutionalisation process in international law. As a wider project, 'constitutionalisation' expresses the optimistic view that international law might come to be articulated, in part through some emergent or self-organising processes, into a scheme that converges in desirable and interesting ways with the typical features of public law in municipal settings. ${ }^{65}$ The constitutionalisation movement within international law looks favourably on the typical administrative law systems of municipalities, as providing models and inspiration for the improvement of regulation at the international level - including ways and means for exerting constraint on executive power. ${ }^{66}$

Some approaches to international constitutionalisation focus on supposed hierarchical relationships among international norms, and the work of Hans Kelsen might be thought of as representing an earlier version of this approach. ${ }^{67}$ In contemporary versions, attention is focused in particular on

\footnotetext{
${ }^{62}$ Susan Marks, The Riddle of All Constitutions (2000); Susan Marks, 'International Law, Democracy and the End of History,' in Gregory Fox and Brad Roth (eds), Democratic Governance and International Law (2000) 532.

${ }^{63}$ The 'political questions doctrine' (under which fact-finding of certain kinds may be treated as an executive matter): see Waldron, above n 8, 1711; also see Rachel Barkow, 'More Supreme than Court? The Fall of the Political Question Doctrine and the Rise of Judicial Supremacy' (2002) 1102 Columbia Law Review 237, 239.

${ }^{64}$ Buchanan's usage of the term Constitutional Positivism in relation to international law is idiosyncratic: Allen Buchanan, Justice, Legitimacy and Self-Determination: Moral Foundations for International Law (2004) 305.

${ }^{65}$ Benedict Kingsbury, Nico Krisch, and Richard Stewart, 'The Emergence of Global Administrative Law' (2005) 68 Law and Contemporary Problems 15; Nico Krisch, 'The Pluralism of Global Administrative Law' (2006) 17 European Journal of International Law 247.

${ }^{66}$ See, similarly, the 'ongoing institutionalization of the international legal order' referred to by Georg Nolte and Helmut Aust, 'Equivocal Helpers - Complicit States, Mixed Messages and International Law' (2009) 58 International and Comparative Law Quarterly 1, 28.

${ }^{67}$ Hans Kelsen, General Theory of Law and State (1945). But 'pigeon-holing' Kelsen is always a difficult exercise.
} 
such superior norms as the peremptory norm or jus cogens. ${ }^{68}$ These international norms, with their evaluative or even frankly moralistic content (such as prohibitions on slavery), are in some ways difficult to localise in terms of the orthodox categories of the sources of international law. ${ }^{69}$ In their connection with larger value systems, which are presumed by international tribunals to underpin and to legitimise them, these peremptory norms to some extent resemble the norms articulated by municipal tribunals as constitutive of the common law. ${ }^{70}$ It might also be said that the peremptory norms have become 'entrenched' in international jurisprudence.

Although the extent of the resemblance should not be exaggerated, there are substantive conceptual links between common law constitutionalism and the form of international constitutionalism that fastens on hierarchical relationships among international norms in general and on the jus cogens in particular. Competing approaches to international constitutionalisation question the validity of peremptory norms and of supposed hierarchical relationships among international norms, favouring the sceptical analysis of Weil in this respect. ${ }^{71}$ The public law contribution to this debate favours a legal positivist style. ${ }^{72}$

\section{CONCLUSION}

The above discussion of the international domain is no more than indicative of some of the interlinking issues that arise from the debate urged by Dyzenhaus between a common law and a positivist approach to constitutionalism. Executive power is a phenomenon not limited by the borders of states, even if systematic and sustainable forms of regulation of that power would seem to have been achieved more successfully within municipalities than beyond them. Thomas v Mowbray, like the Australian Communist Party case before

\footnotetext{
${ }^{68}$ John R Morss, 'Good Global Governance: Custom, the Cosmopolitan and International Law' (2007) 3 International Journal of Law in Context 59.

${ }^{69}$ Malcolm Shaw, International Law (5th ed) (2003) 66, 77.

${ }^{70}$ Gerald Postema, 'Custom in International Law: A Normative Practice Account' in Amanda Perreau-Saussine and James Murphy (eds), The Nature of Customary Law 279; also see Michael Lobban, 'Custom, Common Law Reasoning and the Law of Nations in the Nineteenth Century’ in Perreau-Saussine and Murphy (eds) at 256.

${ }^{71}$ Prosper Weil, 'Towards Relative Normativity in International Law?' (1983) 77 American Journal of International Law 413.

72 Benedict Kingsbury, 'The Concept of “Law” in Global Administrative Law' (2009) 20 European Journal of International Law 23.
} 
it, arose from the attempts of governments to (as they saw it) protect their citizenry from geopolitical threats of an international nature. Notoriously, governments sometimes find it hard to distinguish between protecting their citizenry and protecting themselves. They may also, on occasion, over-extend the notions of 'threat' and of 'emergency'. It would seem impossible entirely to displace the role of political and (broadly speaking) military judgment in seeking value-free historical arbitration over such executive decisions. When the executive's identification of a threat consists of identifying persons as threats (communist sympathisers, associates of terrorist organisations) the imponderables escalate. A sober approach to facts, including notorious facts and constitutional facts, is especially demanded of the judiciary when such perceived threats are responded to by government in the form of legislation. This might be thought of as a correlative of the separation of powers - a separation of responsibilities, as it were.

It was the independence of the judicial branch under Australia's Constitution that made possible the combination of 'success' for the Commonwealth government in Thomas $v$ Mowbray and its 'failure' in the Australian Communist Party case. There seems no good reason to look beyond the separation of powers as such to some higher (or deeper) level of common law values, as Dyzenhaus urges, to explain this set of outcomes. To describe the High Court's cautious reliance on the Constitution's textual provisions as 'superficial' ${ }^{73}$, thus seems mistaken. As Dyzenhaus emphasises, legislation should identify mischiefs and restrain itself from seeking to identify miscreants. In other words, 'Acts of Attainder' (and similar kinds of overreaching) are to be deplored. ${ }^{74}$ In both cases it is a matter of restraint, not superficiality - of 'proper reaching' as opposed to either judicial or legislative overreaching. Likewise, overreaching by the executive is to be regulated. It is thus potentially misleading for the three branches of government to be described as collaborating in a joint 'rule of law project' if, by that description, tensions between the branches are defined as subsidiary to the pursuit of that team project. ${ }^{75}$ Instead, tensions between the three branches are of the essence of the constitutional arrangement. The approach labelled 'constitutional positivism' by Dyzenhaus recognises this.

The question of law's constitutional response to states of emergency must therefore be considered in the light of law's long debates between valuesdriven and procedure-driven accounts of justice, between 'thick' and 'thin'

\footnotetext{
${ }^{73}$ Dyzenhaus, above n 4, 81.

${ }^{74}$ Ibid.

${ }^{75}$ Ibid 147.
} 
accounts of the rule of law and of the separation of powers, between natural law and legal positivist orientations. What has been argued above is summed up by Tamanaha's observation with respect to the rule of law that 'judges, when rendering their decisions, must be committed to searching for the strongest, most correct legal answer ${ }^{76}$ Law is a constraint on the judiciary as well as on the executive. Despite the attractions of an appeal to values and traditions, with the accompanying rhetoric, those features of organised law that we call constitutional features exert their constraining influence in ways that call for a more restrained vocabulary.

\footnotetext{
${ }^{76}$ Tamanaha, Law as a Means to an End, above n 57, 250 (emphasis in original). Also see Maksymilian Del Mar, 'Review of Brian Z Tamanaha, Law as a Means to an End' (2007) 66 Cambridge Law Journal 468.
} 